\title{
Low dose of dichloroacetate infusion reduces blood lactate after submaximal exercise in horses ${ }^{1}$
}

\author{
Guilherme C. Ferraz ${ }^{2 *}$, Helena C.D. Brito ${ }^{2}$, Carolina Berkman ${ }^{2}$, Raquel M. Albernaz ${ }^{2}$, Renatha \\ A. Araújo ${ }^{2}$, Matheus H.M. Silva ${ }^{2}$, Flora H. de F. D’Angelis ${ }^{2}$ and Antonio Queiroz- Neto ${ }^{2}$
}

\begin{abstract}
Ferraz G.C., Brito H.C.D., Berkman C., Albernaz R.M., Araújo R.A., Silva M.H.M., D’Angelis F.H.F. \& Queiroz-Neto A. 2013. Low dose of dichloroacetate infusion reduces blood lactate after submaximal exercise in horses. Pesquisa Veterinária Brasileira 33(1):57-60. Laboratório de Farmacologia e Fisiologia do Exercício Equino, Faculdade de Ciências Agrárias e Veterinárias, Universidade Estadual Paulista, Via de Acesso Prof. Paulo Donato Castellane s/n, Jaboticabal, SP 14884-900, Brazil. E-mail: gferraz@fcav.unesp.br

The acute administration of an indirect activator of the enzyme pyruvate dehydrogenase (PDH) in human athletes causes a reduction in blood lactate level during and after exercise. A single IV dose $\left(2.5 \mathrm{~m} . \mathrm{kg}^{-1}\right)$ of dichloroacetate (DCA) was administered before a submaximal incremental exercise test (IET) with five velocity steps, from $5.0 \mathrm{~m} . \mathrm{s}^{-1}$ for 1 min to $6.0,6.5,7.0$ and $7.5 \mathrm{~m} . \mathrm{s}^{-1}$ every $30 \mathrm{~s}$ in four untrained mares. The blood collections were done in the period after exercise, at times 1, 3, 5, 10, 15 and 20 min. Blood lactate and glucose (mM) were determined electro-enzymatically utilizing a YSI 2300 automated analyzer. There was a $15.3 \%$ decrease in mean total blood lactate determined from the values obtained at all assessment times in both trials after the exercise. There was a decrease in blood lactate $1,3,5,10,15$ and 20 min after exercise for the mares that received prior DCA treatment, with respective mean values of $6.31 \pm 0.90$ vs $5.81 \pm 0.50,6.45 \pm 1.19$ vs $5.58 \pm 1.06,6.07 \pm 1.56$ vs $5.26 \pm 1.12,4.88 \pm 1.61$ vs $3.95 \pm 1.00,3.66 \pm 1.41$ vs $2.86 \pm 0.75$ and $2.75 \pm 0.51$ vs $2.04 \pm 0.30$. There was no difference in glucose concentrations. By means of linear regression analysis, $\mathrm{V}_{140}, \mathrm{~V}_{160}, \mathrm{~V}_{180}$ and $\mathrm{V}_{200}$ were determined (velocity at which the rate heart is $140,160,180$, and 200 beats/minute, respectively). The velocities related to heart rate did not differ, indicating that there was no ergogenic effect, but prior administration of a relatively low dose of DCA in mares reduced lactatemia after an IET.
\end{abstract}

INDEX TERMS: Equine, sodium dichloroacetate, lactatemia, incremental exercise test.

RESUMO-- [Baixa dose de infusão de dicloroacetato reduz o lactato sanguíneo após exercício submáximo em cavalos.] A administração aguda de um ativador indireto da enzima piruvato desidrogenase (PD) em atletas da espécie humana provoca redução na concentração de lactato sanguíneo durante e após exercício. Uma dose única, intravenosa de $2.5 \mathrm{~m} . \mathrm{kg}^{-1}$ de dicloroacetato (DCA) foi administrada antes de um exercício teste incremental submáximo

\footnotetext{
${ }^{1}$ Received on June 5, 2012.

Accepted for publication on November 6, 2012.

${ }^{2}$ Laboratório de Farmacologia e Fisiologia do Exercício Equino (LAFEQ), Departamento de Morfologia e Fisiologia Animal (DMFA), Faculdade de Ciências Agrárias e Veterinárias, FCAV, UNESP-Univ. Estadual Paulista, Câmpus de Jaboticabal, Departamento de Morfologia Animal, Laboratório de Farmacologia e Fisiologia do Exercício (LAFEQ), Via de Acesso Prof. Paulo Donato Castellane s/n, Jaboticabal, SP 14884-900, Brasil. *Corresponding author: gferraz@fcav.unesp.br
}

(ETI) com cinco etapas de velocidade sendo $5,0 \mathrm{~ms}^{-1}$ por 1 minuto e 6,0, 6,5, 7,0, e 7,5 $\mathrm{ms}^{-1}$ a cada 30 segundos em quatro éguas destreinadas. As coletas de sangue foram realizadas no período após o exercício, nos momentos de $1,3,5,10,15$ e $20 \mathrm{~min}$. Lactato e glicose (mM) foram determinados electro-enzimaticamente utilizando um analisador automático (YSI 2300). Houve redução de 15,3\% no lactato sanguíneo total médio que foi determinado a partir dos valores obtidos em todos os momentos de avaliação em ambos os testes, após o exercício. Houve diminuição na lactatemia 1, 3, 5, 10, 15 e 20 minutos após exercício para as éguas que receberam infusão de DCA, com os respectivos valores médios de $6,31 \pm 0,90$ versus $5,81 \pm 0,50,6,45 \pm 1,19$ versus $5,58 \pm 1,06,6,07 \pm 1,56$ versus $5,26 \pm 1,12,4,88 \pm 1,61$ versus $3,95 \pm 1,00,3,66 \pm 1,41$ versus $2,86 \pm 0,75$ e $2,75 \pm 0,51$ versus $2,04 \pm 0,30$. Não houve diferença nas concentrações de glicose. Por meio de análise de regressão linear, $\mathrm{V}_{140}$, 
$\mathrm{V}_{160}, \mathrm{~V}_{180} \mathrm{e} \mathrm{V}_{200}$ foram determinados (velocidades em que as taxas cardíacas alcançam 140, 160, 180 e 200 bpm, respectivamente). As velocidades relacionadas com a frequência cardíaca não diferiram, indicando que não houve efeito ergogênico, mas a administração prévia de uma dose relativamente baixa de DCA em éguas reduziu a lactatemia após um ETI.

TERMOS DE INDEXAÇÃO: Equino, dicloroacetato de sódio, lactatemia, teste de exercício incremental.

\section{INTRODUCTION}

Dichloroacetate is a water-soluble analogue of acetic acid, which indirectly activates the enzyme pyruvate dehydrogenase (PDH, EC 1.2.4.1) by inhibiting the enzymatic activity of pyruvate dehydrogenase kinase (PDHK, EC 2.7.11.2), a protein antagonist of PDH. Specifically, the active "a" form $\left(\mathrm{PDH}_{\mathrm{a}}\right.$ ) accumulates due to the inhibition of PDHK (Howlett et al. 1999). PDH is part of the pyruvate dehydrogenase complex together with enzymes that participate in the tricarboxylic acid (TCA) cycle and b-oxidation, which under aerobic conditions, converts pyruvate present in the mitochondrial matrix, into carbon dioxide and a two-carbon group, acetyl-CoA, in the reaction of oxidative decarboxylation (Stacpoole et al. 2003, Robey \& Martin 2011).

From a holistic view, with respect to the pharmacological and therapeutic potential of DCA in reducing lactatemia, besides its application in studies on ergogenic efficacy in exercise, other types of applications within veterinary medicine are possible in basic studies focused on the role of lactate as a mediator of ventilatory responses (Gargalione et al. 2003) as well as in therapies for endotoxic shock (Levy et al. 2007), in respiratory illnesses (Calvert et al. 2008 ) or as adjuvants in anticancer therapeutics (Robey \& Martin 2011). Currently, our laboratory is developing experimental models with acute DCA administration in horses as well as Wistar rats and its possible effects on muscle lactate production and eventual interactions with bioenergetic pathways in muscle and on acid-base balance, among other effects.

Previous studies demonstrated the reduction of exercise-induced lactatemia by DCA. In humans (Howlett et al. 1999), the intravenous administration of DCA before exercise activated $\mathrm{PDH}$ and promoted the subsequent acetylation of free CoA, reducing the production of blood lactate by approximately $18 \%$.

Given the effectiveness of DCA in increasing the rate of oxidation of pyruvate, some authors have indicated for horses the utilization of this substance as an ergogenic supplement (Harris \& Harris, 1998). Obviously, from the point of view of rules that regulate the utilization of substances in athletic horses, established by responsible authorities such as the Fédération Equestre Internationale (FEI) or Association of Racing Commissioners International (ARCI), the utilization of DCA could be sanctioned. However, there are no studies in this species that focus on the utilization of DCA and its possible efficacy in reducing lactatemia and possibly improving performance, in an experimental model that involves physical effort. Our hypothesis was that the administration of $2.5 \mathrm{mg} \cdot \mathrm{kg}^{-1}$ DCA, prior to exercise, would reduce lactatemia in horses after physical effort of submaximal intensity. Investigators have indicated the utilization of DCA based on evidence obtained in dogs (Timmons et al. 1996) and in humans (Timmons et al. 1998). Therefore, the aim of this study was to determine the effects of the administration of a single dose of DCA on lactatemia during recovery in mares submitted to an incremental exercise test on a treadmill.

\section{MATERIALS AND METHODS}

\section{Animals and drug administration}

After an acclimation period of 20 days on treadmill exercise (Galloper ${ }^{\circledR} 5500$, Sahinco), four untrained crossbreed mares with an average age of $7 \pm 2 \mathrm{yr}$, with a mean weight of $387 \pm 14 \mathrm{~kg}$, received an intravenously injection of $2.5 \mathrm{mg} \mathrm{kg}^{-1}$, body weight of a solution of $80 \mathrm{mg} \mathrm{ml}^{-1}$ DCA, 10 min before an IET. The mares were submitted to two IET separated by a three-day interval. Saline was given in the control trials. On the test days, the mares received either DCA or saline infusion in a randomized order. The mares were kept in a paddock of Brachiaria sp grass with ad libitum access to water and Cynodon sp. hay and mineralized salt. Each horse was also feed with $2-3 \mathrm{~kg}$ /day of a commercial concentrate, $2 \mathrm{~h}$ before the tests. The Institutional Animal Care and Use Committee at São Paulo State University approved the study.

\section{Incremental exercise test, blood samples and analysis}

The total duration of IET was $8.0 \mathrm{~min}$. The treadmill was inclined by $5 \%$ and after a warm-up period of $5 \mathrm{~min}$ at trot (3.0$3.5 \mathrm{~m} . \mathrm{s}^{-1}$ ), the velocity of the treadmill was increased to $5.0 \mathrm{~m} . \mathrm{s}^{-1}$, for $1 \mathrm{~min}$, and every $30 \mathrm{~s}$ to $6.0,6.5,7.0$ and $7.5 \mathrm{~m} . \mathrm{s}^{-1}$. Blood lactate and glucose concentration were assessed electro-enzymatically (YSI 2300, Yellow Springs Instrument, USA). Blood samples were collected before ( $-10 \mathrm{~min})$ the administration of DCA and in the active cooling down period $\left(2.5 \mathrm{~m} . \mathrm{s}^{-1}\right)$ at times $1,3,5,10,15$ and $20 \mathrm{~min}$ after IET. The means of total blood lactate generated were determined from the values obtained at all assessment times in both trials after IET. Heart rate was determined with a digital heart rate monitor designed for horses (Equine RS 800 CX G3 Polar, USA), where three measurements were taken at each exercise step, and by means of linear regression analysis, $\mathrm{V}_{140}, \mathrm{~V}_{160}, \mathrm{~V}_{180}$ and $\mathrm{V}_{200}$, variables used to assess submaximal workload, were determined.

\section{Statistical analysis}

Statistical analysis was performed utilizing the computational program SAS System for Windows V9, and the results presented as mean \pm standard error of the mean. Prior to the analyses, the Shapiro Wilk test for normality and Levene's test for homogeneity were carried out. The effect of exercise and of DCA administration on lactatemia was studied using analysis of variance (ANOVA) for repeated measures, with the aim of determining significant differences within each effort step. Student's t-test for paired samples was used to compare differences between trials and mean total blood lactate. The level of significance was set at $5 \%(P<0.05)$.

\section{RESULTS}

The two IET were carried out at similar workload, because they showed the same heart rate peak. There was a reduction of $15.3 \%$ in total lactatemia (Table 1). During the 


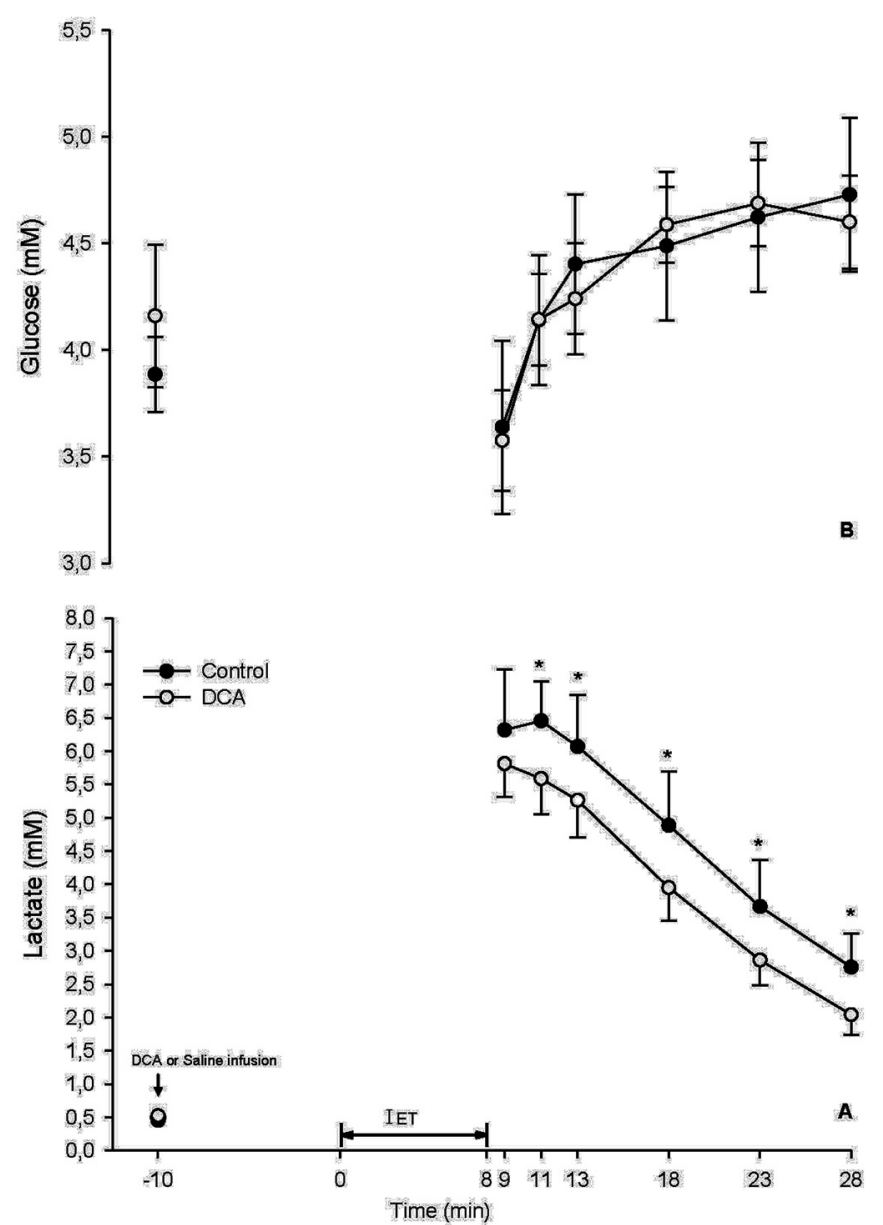

Fig.1. Lactatemia and glucose recovery after IV administration of $2.5 \mathrm{mg} . \mathrm{kg}^{-1}$ of sodium dichloroacetate in mares during incremental exercise (IET) on a treadmill. $\mathrm{N}=4$ for $\mathrm{C}$ (control) and DCA (dichloroacetate). ${ }^{*}$ Significant decrease in relation to control trial.

Table 1. Mare's variable profile in the exercise test

\begin{tabular}{lc}
\hline \multicolumn{1}{c}{ Variable } & Mean values (Min-Max) \\
\hline $\begin{array}{l}\text { Heart rate, bpm (-10min) } \\
\text { Control }\end{array}$ & $40 \pm 2(34-44)$ \\
DCA & $42 \pm 1(37-46)$ \\
Peak heart rate, bpm & \\
$\quad$ Control & $201 \pm 16(185-212)$ \\
$\quad$ DCA & $201 \pm 12(180-219)$ \\
Lactate, mM $(-10 \mathrm{~min})$ & \\
$\quad$ Control & $0.45 \pm 0.10(0.37-0.60)$ \\
$\quad$ DCA & $0.52 \pm 0.06(0.44-0.58)$ \\
Total lactate, mM & \\
$\quad$ Control & \\
DCA & $5.02 \pm 1.93(1.46-8.81)$ \\
& $4.25 \pm 1.67^{*}(1.25-6.95)$
\end{tabular}

recovery phase (Fig.1A), there was a decrease in lactatemia 1 and 20 min after exercise in the mares that received prior treatment with DCA, when compared to the control group, with respective means of $6.31 \pm 0.90$ vs $5.81 \pm 0.50$ and $2.75 \pm 0.51$ vs $2.04 \pm 0.30 \mathrm{mM}$. The Figure $1 \mathrm{~B}$ shows that between the trials there was no difference in blood glucose concentrations. The control and experimental trials showed no differences in heart rate during submaximal exercise in relation to velocity of exercise, $\mathrm{V}_{140}, \mathrm{~V}_{160}, \mathrm{~V}_{180}$ and $\mathrm{V}_{200}$ (Fig.2).

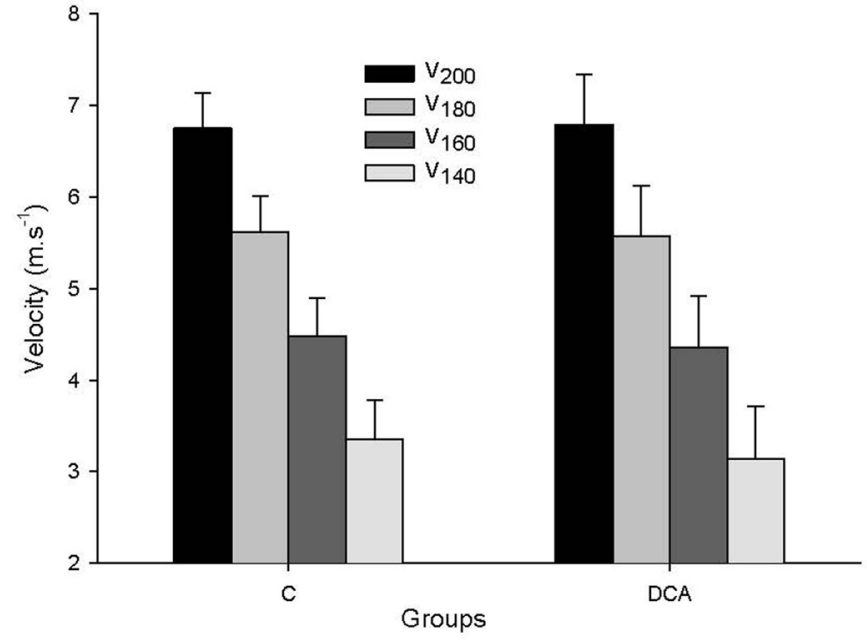

Fig.2. Velocities at which the heart rate reached 140, 160, 180, and 200 beats/min after IV administration of $2.5 \mathrm{mg} \cdot \mathrm{kg}^{-1}$ of sodium dichloroacetate in mares during incremental exercise on a treadmill. $\mathrm{N}=4$ for $\mathrm{C}$ (control) and DCA (dichloroacetate).

\section{DISCUSSION}

The results obtained in this study are preliminary, with some limitation due to the utilization of only four mares. Therefore, some aspects considered in the discussion have a descriptive nature, information which may be useful to future studies, with respect to possible mechanisms of action in skeletal muscle fibers involved in acute DCA administration in horses. Nonetheless, the data presented in this short communication are encouraging for our research group; despite the relatively small sample, there was a clear tendency of a reduction in lactatemia, which has not been previously published for the equine species.

Despite the early stage of this research in our laboratory and preliminary nature of the results of a single administration dose, this is the first study to demonstrate the efficacy of the administration of $2.5 \mathrm{mg} \mathrm{kg}^{-1}$ DCA in horses, as a drug that reduces lactate production after progressive exercise on a treadmill. We used a relatively low dose when compared to other studies, mainly in humans, which reported doses of DCA varying between 25 and $100 \mathrm{mg}^{\mathrm{kg}} \mathrm{kg}^{-1}$. Therefo$\mathrm{re}$, it is clear that further dose-response studies are needed to determine the maximal hypolactatemia effect of DCA in horses undergoing physical exercise, since DCA appears to be essentially dose dependent (Arslan et al. 2004).

In horses (Sloet van Oldruitenborgh-Oosterbaan et al. 2002, Lindinger 2011) and humans (Böning et al. 2005), some authors have reported an increase in the production of lactate, during intense exercise, with a consequent induction of fatigue. However, our results did not indicate that the reduction in lactatemia enhanced resistance to physical effort. Still, in humans (Calvert et al. 2008), the administration of DCA was shown to reduce lactatemia, modulating the tolerance to the stressor stimulus imposed by exercise. However, Rossiter et al. (2003) asserted that the reduction of lactate induced by DCA can lead to a reduction in the accumulation of other metabolites that induce fatigue such as $\mathrm{P}_{\mathrm{i}}, \mathrm{H}^{+}$and $\mathrm{H}_{2} \mathrm{PO}_{4}$. 
However, with respect to the possible beneficial effect of lactate reduction by DCA, promoting an increase in performance during exercise test, aerobic capacity is related to cardiac output ( $\dot{Q}$ ) by means of the classical equation of Fick $\left[\mathrm{V} \mathrm{O}_{2}=\dot{\mathrm{Q}} \times\left(\mathrm{a}-\mathrm{vO} \mathrm{O}_{2}\right)\right]$. Due to the great participation of $\dot{Q}$ in maximal aerobic capacity $\left(\mathrm{V}_{\mathrm{C}_{\max }}\right.$ ), heart rate also shows a linear relation with $\mathrm{V} \mathrm{O}_{2}$ (Achten \& Jeukendrup 2003). Therefore, the utilization of indices that relate heart rate to intensity of effort is capable of indirectly predicting the dynamics of the consumption of oxygen in an incremental exercise test (Gramkow \& Evans 2006). However, our preliminary results indicate that despite the evident tendency of reduction in lactatemia, the administration of DCA at the dose utilized in this study did not alter the cardiac response of the mares despites the small likelihood of diagnosing a reduced performance by using heart rate.

Is reduction of lactate production necessarily a good thing in a horse or mare with a characteristically high oxidative capacity and $\mathrm{V}_{2_{\max }}$ ? Perhaps it is not, because lactate is essential for maintaining the redox state of the cytosol by the oxidation of NADH to $\mathrm{NAD}^{+}$via NADH shuttles, malate-aspartate or glyceraldehyde-3-phosphate. If the NADH shuttles do not oxidize NAD to NADH, the conversion of glyceraldehyde-3-phosphate to 1,3 biphosphoglycerate, the first reaction of the energy-producing phase of glycolysis would be affected considerably, in turn affecting both the glycolytic and oxidative (TCA cycle) production of ATP (Bartlett \& Evans 2010, Robergs et al. 2011). However, the decrease in lactate production observed in this study was not sufficient to alter the fitness of the mares.

Blood glucose did not differ between trials at any time. The same result was obtained in a study (Howlett et al. 1999) that determined the effect of DCA infusion on skeletal muscle metabolism in humans at the beginning of exercise. However, the cited study reported increased intramuscular glucose levels, reflecting an increase in glycolytic flux. Thus, further studies in horses are needed to elucidate the exercise-DCA-muscle energy substrate triad.

\section{CONCLUSION}

In conclusion, a single dose of DCA did not have any beneficial effect on aerobic or ergogenic capacity, but did reduce lactatemia during recovery in mares submitted to an incremental exercise test.

Acknowledgements.- To Professor Luciane Helena Gargaglioni Batalhão of the Department of Animal Morphology and Physiology of FCAV/
Unesp/Jaboticabal for scientific discussion that prompted our interest in the study of dichloroacetate in horses. Dr. A. Leyva helped with English translation and editing of the manuscript.

\section{REFERENCES}

Achten J. \& Jeukendrup A.E. 2003. Heart rate monitoring: applications and limitations. Sports Med. 33:517-538.

Bartlett M.F. \& Lehnhard R.A. 2010. The lactate paradox: A review. Comp. Exerc. Physiol. 7:1-13.

Calvert L.D., Shelley R., Singh S.J., Greenhaff P.L., Bankart J., Morgan M.D. \& Steiner M.C. 2008. Dichloroacetate enhances performance and reduces blood lactate during maximal cycle exercise in chronic obstructive pulmonary disease. Am. J. Resp. Crit. Care Med. 177:1090-1094.

Gargaglioni L.H., Bicego K.C., Steiner A.A. \& Branco L.G.S. 2003. Lactate as modulator of hypoxia-induced hyperventilation. Resp. Physiol. Neur. 348:1-8

Gramkow H.L. \& Evans D.L. 2006. Correlation of race earnings with velocity at maximal heart rate during a field exercise test in thoroughbred racehorses. Equine Vet. J. 36(Suppl.):118-122.

Harris P.A. \& Harris R.C. 1998. Nutritional ergogenic aids in the horse: Uses and abuses. Proc. Conference of Equine Sports Medicine Science, Cordoba, p.203-218.

Howlett R., Heigenhauser G., Hultman E., Hollidge-Horvat M. \& Spriet L. 1999. Effects of dichloroacetate infusion on human skeletal muscle metabolism at the onset of exercise. Am. J. Physiol. Endocr. M277: E18-E25.

Levy B., Mansart A., Montemont C., Gibot S., Mallie J.P., Regnault V., Lecompte T. \& Lacolley P. 2007. Myocardial lactate deprivation is associated with decreased cardiovascular performance, decreased myocardial energetics, and early death in endotoxic shock. J. Intensive Care Med. 33:495-502.

Lindinger M.I. 2011. Lactate: Metabolic fuel or poison for racehorses? Exp. Physiol. 96:261.

Robey I.F. \& Martin N.K. 2011. Bicarbonate and dichloroacetate: Evaluating $\mathrm{pH}$ altering therapies in a mouse model for metastatic breast cancer. BMC Cancer 235:1471-1481.

Robergs R.A. 2011. Nothing 'evil' and no 'conundrum' about muscle lactate production. Exp. Physiol. 96:1097-1098.

Rossiter H.B., Ward S.A., Howe F.A., Wood D.M., Kowalchuk J.M., Griffiths J.R. \& Whipp B.J. 2003. Effects of dichloroacetate on $\dot{V} \mathrm{O}_{2}$ and intramuscular ${ }^{31} \mathrm{P}$ metabolite kinetics during high-intensity exercise in humans. J. Appl. Physiol. 95:1105-1115.

Stacpoole P.W., Nagaraja N.V. \& Hutson A.D. 2003. Efficacy of dichloroacetate as a lactate-lowering drug. J. Clin. Pharmacol. 43:683-691.

Timmons J.A., Poucher S.M., Constantin-Teodosiu D., Worrall V., MacDonald I.A. \& Greenhaff P.L. 1996. Increased acetyl group availability enhances contractile function of canine skeletal muscle during ischemia. J. Clin. Invest. 97:879-883.

Timmons J.A., Gustavsson T., Sundberg C.J., Jansson E., Hultman E., Kaiser L., Chwalbinska-Moneta J., Constantin-Teodosiu D., Macdonald I.A. \& Greenhaff P.L. 1998. Substrate availability limits human skeletal muscle oxidative ATP regeneration at the onset of ischemic exercise. J. Clin. Invest. 101:79-86. 